\title{
Observing atmospheric formaldehyde (HCHO) from space: validation and intercomparison of six retrievals from four satellites (OMI, GOME2A, GOME2B, OMPS) with SEAC ${ }^{4} \mathrm{RS}$ aircraft observations over the southeast US
}

\author{
Lei Zhu ${ }^{1}$, Daniel J. Jacob ${ }^{1,2}$, Patrick S. Kim ${ }^{2}$, Jenny A. Fisher ${ }^{3,4}$, Karen Yu ${ }^{1}$, Katherine R. Travis ${ }^{1}$, \\ Loretta J. Mickley ${ }^{1}$, Robert M. Yantosca ${ }^{1}$, Melissa P. Sulprizio ${ }^{1}$, Isabelle De Smedt ${ }^{5}$, Gonzalo González Abad ${ }^{6}$, \\ Kelly Chance $^{6}$, Can Li ${ }^{7,8}$, Richard Ferrare ${ }^{9}$, Alan Fried ${ }^{10}$, Johnathan W. Hair ${ }^{9}$, Thomas F. Hanisco ${ }^{8}$, Dirk Richter ${ }^{10}$, \\ Amy Jo Scarino ${ }^{11}$, James Walega ${ }^{10}$, Petter Weibring ${ }^{10}$, and Glenn M. Wolfe ${ }^{8,12}$ \\ ${ }^{1}$ John A. Paulson School of Engineering and Applied Sciences, Harvard University, Cambridge, MA, USA \\ ${ }^{2}$ Department of Earth and Planetary Sciences, Harvard University, Cambridge, MA, USA \\ ${ }^{3}$ Centre for Atmospheric Chemistry, School of Chemistry, University of Wollongong, Wollongong, NSW, Australia \\ ${ }^{4}$ School of Earth and Environmental Sciences, University of Wollongong, Wollongong, NSW, Australia \\ ${ }^{5}$ Belgian Institute for Space Aeronomy (BIRA-IASB), Brussels, Belgium \\ ${ }^{6}$ Harvard-Smithsonian Center for Astrophysics, Cambridge, MA, USA \\ ${ }^{7}$ Earth System Science Interdisciplinary Center, University of Maryland, College Park, Maryland, USA \\ ${ }^{8}$ NASA Goddard Space Flight Center, Greenbelt, Maryland, USA \\ ${ }^{9}$ NASA Langley Research Center, Hampton, VA 23681, USA \\ ${ }^{10}$ Institute of Arctic and Alpine Research, University of Colorado, Boulder, CO, USA \\ ${ }^{11}$ Science Systems and Applications, Inc., Hampton, VA, USA \\ ${ }^{12}$ Joint Center for Earth Systems Technology, University of Maryland Baltimore County, Baltimore, Maryland, USA
}

Correspondence to: Lei Zhu (leizhu@ fas.harvard.edu)

Received: 24 February 2016 - Published in Atmos. Chem. Phys. Discuss.: 14 March 2016

Revised: 11 September 2016 - Accepted: 18 October 2016 - Published: 1 November 2016

\begin{abstract}
Formaldehyde (HCHO) column data from satellites are widely used as a proxy for emissions of volatile organic compounds (VOCs), but validation of the data has been extremely limited. Here we use highly accurate $\mathrm{HCHO}$ aircraft observations from the NASA SEAC ${ }^{4}$ RS (Studies of Emissions, Atmospheric Composition, Clouds and Climate Coupling by Regional Surveys) campaign over the southeast US in August-September 2013 to validate and intercompare six retrievals of $\mathrm{HCHO}$ columns from four different satellite instruments (OMI, GOME2A, GOME2B and OMPS; for clarification of these and other abbreviations used in the paper, please refer to Appendix A.) and three different research groups. The GEOS-Chem chemical transport model is used as a common intercomparison platform. All retrievals feature a HCHO maximum over Arkansas and Louisiana, consistent with the aircraft observations and reflecting high emissions
\end{abstract}

of biogenic isoprene. The retrievals are also interconsistent in their spatial variability over the southeast US $(r=0.4$ 0.8 on a $0.5^{\circ} \times 0.5^{\circ}$ grid) and in their day-to-day variability $(r=0.5-0.8)$. However, all retrievals are biased low in the mean by $20-51 \%$, which would lead to corresponding bias in estimates of isoprene emissions from the satellite data. The smallest bias is for OMI-BIRA, which has high corrected slant columns relative to the other retrievals and low scattering weights in its air mass factor (AMF) calculation. OMIBIRA has systematic error in its assumed vertical $\mathrm{HCHO}$ shape profiles for the AMF calculation, and correcting this would eliminate its bias relative to the $\mathrm{SEAC}{ }^{4} \mathrm{RS}$ data. Our results support the use of satellite $\mathrm{HCHO}$ data as a quantitative proxy for isoprene emission after correction of the low mean bias. There is no evident pattern in the bias, suggesting 
that a uniform correction factor may be applied to the data until better understanding is achieved.

\section{Introduction}

Formaldehyde (HCHO) is a high-yield product from the atmospheric oxidation of volatile organic compounds (VOCs). Methane oxidation largely defines the tropospheric $\mathrm{HCHO}$ background. Higher HCHO concentrations over continents are due to short-lived non-methane VOCs (NMVOCs). Loss of $\mathrm{HCHO}$ is mainly by photolysis and oxidation by $\mathrm{OH}$, resulting in an atmospheric lifetime on the order of a few hours. $\mathrm{HCHO}$ is detectable from space by solar UV backscatter between 325 and $360 \mathrm{~nm}$ (Chance et al., 2000). HCHO column data from satellites have been used in a number of studies as top-down constraints on NMVOC emissions from biogenic, anthropogenic and open fire sources (Palmer et al., 2003; Shim et al., 2005; Stavrakou et al., 2009; Marais et al., 2012; Barkley et al., 2013; Zhu et al., 2014). However, the satellite data have received little validation so far. Here we validate and intercompare six different $\mathrm{HCHO}$ retrievals from four satellites instruments (OMI, GOME2A, GOME2B, OMPS) and three different groups with aircraft observations from the NASA SEAC ${ }^{4}$ RS (Studies of Emissions, Atmospheric Composition, Clouds and Climate Coupling by Regional Surveys) campaign over the southeast US in summer 2013 (Toon et al., 2015).

HCHO columns (molecules $\mathrm{cm}^{-2}$ ) have been continuously observed from space since GOME (1996-2003; Chance et al., 2000) and SCIAMACHY (2003-2012; Wittrock et al., 2006). Observations are presently available from OMI (2004-), GOME2A (2006-), OMPS (2011-) and GOME2B (2012-). The satellite detects a slant column density of HCHO along the atmospheric path of the solar radiation backscattered to the satellite from the surface and the atmosphere. Conversion to a vertical column is done with an air mass factor (AMF) that depends on the satellite viewing geometry, the surface albedo, the vertical $\mathrm{HCHO}$ profile, and the vertical distributions of clouds and aerosols (Palmer et al., 2001). Scattering by air molecules causes the AMF to be highly sensitive to the $\mathrm{HCHO}$ vertical distribution, which has to be independently specified (Hewson et al., 2015). The resulting $\mathrm{HCHO}$ vertical column retrieved from the satellite includes errors from the slant column fitting and from the AMF estimate (Marais et al., 2012).

Validation of HCHO satellite data sets has been extremely limited due to (1) the large noise in individual satellite retrievals, requiring extensive data averaging to enhance detection, and (2) the limited number of HCHO column measurements acquired from aircraft or from the ground. Martin et al. (2004) validated GOME HCHO columns with aircraft observations in eastern Texas averaged over two campaigns (June-July 1999 and August-September 2000) and found GOME to be too high by $16 \%$ on average. Comparison of SCIAMACHY data to ground-based measurements of HCHO columns found no significant mean bias (Wittrock et al., 2006; Vigouroux et al., 2009). Barkley et al. (2013) found that OMI was $37 \%$ lower than aircraft measurements made in October 2005 over Guyana. Validation with ground-based remotely sensed vertical profiles indicates a $20-40 \%$ underestimate in OMI and GOME2 data (De Smedt et al., 2015).

The SEAC ${ }^{4}$ RS campaign offers an exceptional opportunity for validating satellite $\mathrm{HCHO}$ data. HCHO columns over the southeast US in summer are among the highest in the world (Kurosu et al., 2004), due to large emissions of biogenic isoprene from vegetation (Guenther et al., 2006). Several studies have used $\mathrm{HCHO}$ data from space as constraints on isoprene emission in the southeast US (Palmer et al., 2006; Millet et al., 2008; Valin et al., 2016). The SEAC ${ }^{4} \mathrm{RS}$ aircraft payload included two independently calibrated in situ HCHO measurements: the Compact Atmospheric Multispecies Spectrometer (CAMS) (Richter et al., 2015) and the NASA GSFC In Situ Airborne Formaldehyde (ISAF) (Cazorla et al., 2015). CAMS is a mid-IR laser-based spectrometer, which has $1 \mathrm{~Hz}$ detection sensitivity of $\sim 40$ ppt HCHO (Richter et al., 2015). ISAF uses rotational-statespecific laser for detection of $\mathrm{HCHO}$ with a $1 \mathrm{~Hz}$ detection limit of 36 ppt (Cazorla et al., 2015).

The SEAC ${ }^{4} \mathrm{RS}$ aircraft did not conduct direct satellite validation profiles; hence we did not apply the direct validation method. Instead we use here an indirect validation method involving joint comparisons of satellite and in situ $\mathrm{HCHO}$ observations with the GEOS-Chem chemical transport model (CTM; Bey et al., 2001). Satellite and in situ observations do not need to be concurrent, thus increasing considerably the range of data and conditions that can be used for validation.

\section{Satellite data sets}

Table 1 lists the six different satellite retrievals of HCHO produced during the SEAC ${ }^{4} \mathrm{RS}$ campaign. Additional details on the retrievals are in the Supplement. These are from four satellite instruments (OMI, GOME2A, GOME2B, OMPS) on different platforms, with retrievals produced by independent groups for OMI and OMPS. OMI, flown on the NASA Aura research satellite, has much higher spatial resolution than the other instruments. GOME2A and GOME2B are the first successive instruments of a long-term operational commitment by the EUMETSAT (European Organisation for the Exploitation of Meteorological Satellites) agency for observing atmospheric composition from space (Callies et al., 2000). OMPS is the first instrument of a similar long-term operational commitment by NOAA in the US (Dittman et al., 2002).

All instruments in Table 1 provide dense data sets, with full coverage of the Earth's surface on 1 day for OMI and OMPS, 3 days for GOME2A (since July 2013) and 
Table 1. Satellite HCHO products validated and intercompared in this work ${ }^{\mathrm{a}}$.

\begin{tabular}{|c|c|c|c|c|c|c|}
\hline Retrieval & $\begin{array}{r}\text { Nadir } \\
\text { resolution }\left(\mathrm{km}^{2}\right)\end{array}$ & $\begin{array}{r}\text { Local } \\
\text { viewing time }\end{array}$ & $\begin{array}{r}\text { Fitting } \\
\text { windows }(\mathrm{nm})\end{array}$ & $\begin{array}{l}\text { Chemical } \\
\text { transport model }^{\mathrm{b}}\end{array}$ & $\begin{array}{r}\text { Detection limit } \\
\left(10^{16} \text { molecules }\right. \\
\left.\mathrm{cm}^{-2}\right)\end{array}$ & Reference $^{c}$ \\
\hline OMI-SAO (V003) & $24 \times 13$ & 1330 & $328.5-356.5$ & GEOS-Chem v09-01-03 & 1.0 & (1) \\
\hline OMI-BIRA (V14) & $24 \times 13$ & 1330 & $328.5-346.0$ & IMAGES v2 & 0.7 & (2) \\
\hline GOME2A-BIRA (V14) & $40 \times 40$ & 0930 & $328.5-346.0$ & IMAGES v2 & 0.8 & (3) \\
\hline GOME2B-BIRA (V14) & $80 \times 40$ & 0930 & $328.5-346.0$ & IMAGES v2 & 0.5 & (2) \\
\hline OMPS-SAO & $50 \times 50$ & 1330 & $327.7-356.0$ & GEOS-Chem v09-01-03 & 0.75 & (4) \\
\hline OMPS-PCA & $50 \times 50$ & 1330 & $328.5-356.5$ & GMI & 1.2 & (5) \\
\hline
\end{tabular}

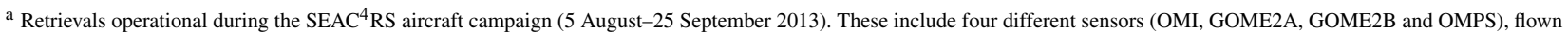
on different platforms, with different retrievals for OMI and OMPS produced by the Harvard Smithsonian Astrophysical Observatory (SAO), the Belgian Institute for Space Aeronomy (BIRA), and the NASA Goddard Space Flight Center by principal component analysis (PCA). Further retrieval details are in the Supplement. ${ }^{\text {b }}$ Chemical transport model (CTM) supplying the normalized mixing ratio vertical profiles (shape factors) and background correction $\left(\Omega_{0}\right.$; see Sect. 2) used in the retrieval. References are ChanMiller et al. (2014) for GEOS-Chem v09-01-03, Stavrakou et al. (2009) for IMAGES v2 and Rodriguez (1996) for GMI. ${ }^{c}$ (1) González Abad et al. (2015); (2) De Smedt et al. (2015); (3) De Smedt et al. (2012); (4) González Abad et al. (2016); (5) Li et al. (2015). OMI-SAO data were downloaded from http://disc.sci.gsfc.nasa.gov/Aura/data-holdings/OMI/omhcho_v003.shtml. GOME2A-BIRA and GOME2B-BIRA data were downloaded from http://h2co.aeronomie.be. Other data were courtesy of the retrieval groups.

1.5 days for GOME2B. The single-scene detection limit $\left(0.5-1.0 \times 10^{16}\right.$ molecules $\left.\mathrm{cm}^{-2}\right)$ is determined by uncertainty in fitting the backscattered solar spectra for SAO retrievals (González Abad et al., 2015, 2016) and is estimated as the standard deviation of HCHO column amounts over the remote Pacific for BIRA retrievals (De Smedt et al., 2012, 2015). AMFs add another error of 30-100\% for single-scene retrievals (González Abad et al., 2015). OMPS-PCA has a single-scene detection limit of $1.2 \times 10^{16}$ molecules $\mathrm{cm}^{-2}$ estimated as 4 times the standard deviation of $\mathrm{HCHO}$ column amounts over the Pacific Ocean (Li et al., 2015). Uncertainties in HCHO columns can be reduced for monthly means, down to 20-40\% for GOME-2A (De Smedt et al., 2008), $38 \%$ for OMI, $46 \%$ for GOME-2B and $\sim 30 \%$ for OMPS, corresponding to $0.1-0.4 \times 10^{16}$ molecules $\mathrm{cm}^{-2}$ over the southeast US. Here and elsewhere, we use only satellite pixels with solar zenith angle less than $60^{\circ}$, cloud fraction less than 0.3, row anomalies (for OMI) screened, quality check passed (for SAO retrievals) and vertical column density within the -0.5 to $10 \times 10^{16}$ molecules $\mathrm{cm}^{-2}$ range. The last criterion excludes data that have passed quality tests but are nevertheless suspect as outliers. It excludes $5.8 \%$ of the data.

All retrievals (except OMPS-PCA) fit the slant column density (SCD) of HCHO from the backscattered solar radiance spectra and then subtract the SCD over the remote Pacific (known as reference sector correction) for the same latitude and observing time to remove offsets (Khokhar et al., 2005). The resulting corrected $\mathrm{SCD}\left(\Delta \Omega_{\mathrm{S}}\right)$ thus represents a HCHO enhancement over the Pacific background. Additional details on reference sector correction are in the Supplement. $\Delta \Omega_{\mathrm{S}}$ is converted to the HCHO vertical column density $(\mathrm{VCD}, \Omega$ ) by applying an $\mathrm{AMF}$ and a background correction $\left(\Omega_{\mathrm{o}}\right)$ :

$\Omega=\frac{\Delta \Omega_{\mathrm{S}}}{\mathrm{AMF}}+\Omega_{\mathrm{o}}$
The background correction, $\Omega_{\mathrm{o}}$, is the HCHO vertical column simulated by a CTM (Table 1) for the remote Pacific at the corresponding latitude and observing time. OMPS-PCA derives the VCD in one step using spectrally varying Jacobians (Li et al., 2015).

The AMF depends on the solar zenith angle $\left(\theta_{Z}\right)$ and satellite viewing angle $\left(\theta_{V}\right)$, on the scattering properties of the atmosphere and the surface, and on the vertical profile of HCHO concentration. It is computed following Palmer et al. (2001) as the product of a geometrical AMF $\left(\mathrm{AMF}_{\mathrm{G}}\right)$ describing the viewing geometry in a non-scattering atmosphere and a correction with scattering weights $w$ applied to the vertical shape factors $S$ :

$$
\begin{aligned}
& \mathrm{AMF}_{\mathrm{G}}=\frac{1}{\cos \theta_{Z}}+\frac{1}{\cos \theta_{V}}, \\
& \mathrm{AMF}=\mathrm{AMF}_{\mathrm{G}} \int_{P_{\mathrm{S}}}^{0} w(p) S(p) \mathrm{d} p .
\end{aligned}
$$

Here the integration is over the pressure $(p)$ coordinate from the surface $\left(p_{\mathrm{S}}\right)$ to the top of the atmosphere. The shape factor is the normalized vertical profile of mixing ratio: $S(p)=C(p) \Omega_{\mathrm{A}} / \Omega$, where $C$ is the HCHO mixing ratio and $\Omega_{\mathrm{A}}$ is the total air column (Palmer et al., 2001). The scattering weight measures the sensitivity of the backscattered radiation to the presence of $\mathrm{HCHO}$ at a given pressure. Impact of aerosols is not explicitly addressed in HCHO retrievals because it is considered to be implicitly included in the cloud correction scheme to the scattering weights (De Smedt et al., 2012, 2015).

All satellite data products (except OMPS-PCA) in Table 1 report for each retrieval $\Omega, \mathrm{AMF}_{\mathrm{G}}$ and $\mathrm{AMF}$, as well as the scattering weights $w(p)$ or equivalent averaging kernels $A(p)=w(p) /$ AMF (Eskes and Boersma, 2003). The BIRA retrievals report in addition the corrected SCD $\Delta \Omega_{\mathrm{S}}$ and background correction $\Omega_{0}$. To be able to interpret differences between retrievals, we obtained the $\Omega_{0}$ values used by 

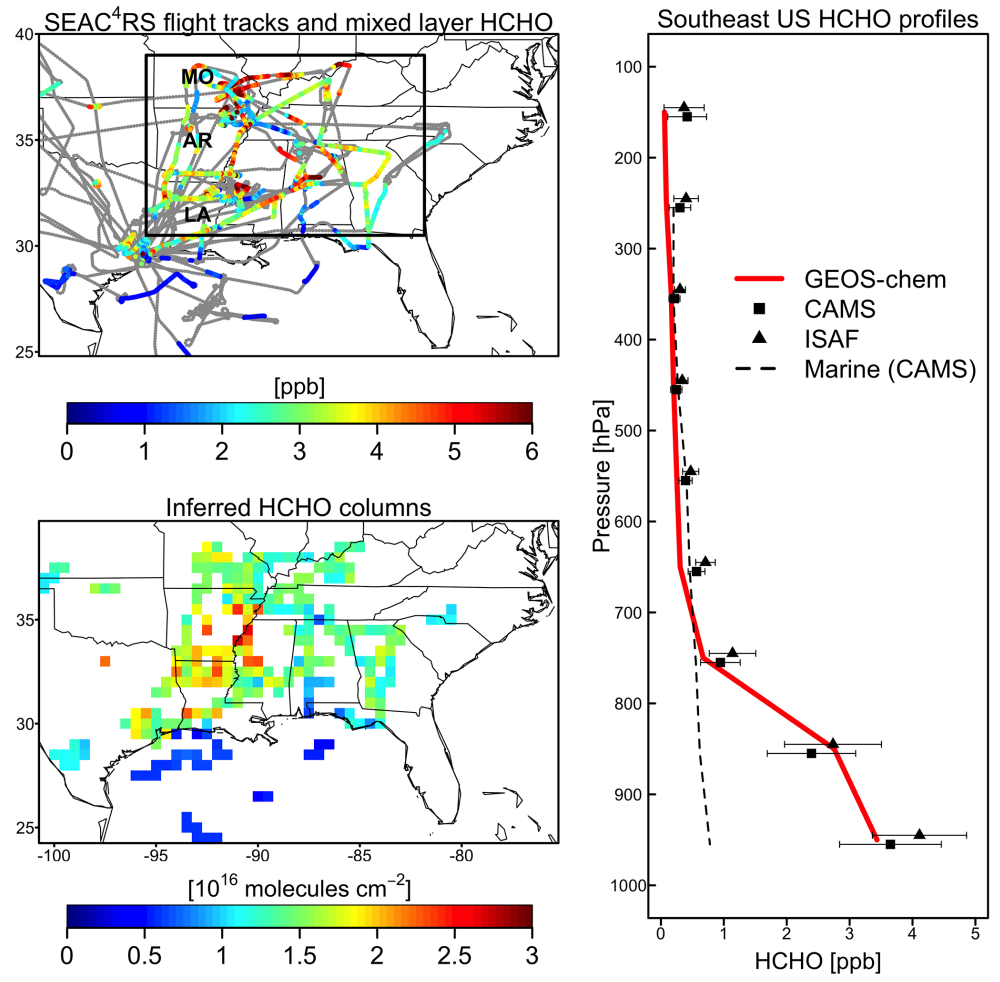

Figure 1. Formaldehyde (HCHO) concentrations along SEAC ${ }^{4} \mathrm{RS}$ aircraft flight tracks (5 August-25 September 2013). The top left panel shows the DC-8 flight tracks (in grey) and the CAMS measurements aboard the aircraft in the mixed layer. The mixed layer is the convectively unstable region of the atmosphere in contact with the surface, diagnosed locally from aerosol lidar observations aboard the aircraft (DIALHSRL Mixed Layer Heights README, 2014) and typically extending to 1-3 km altitude. The states of Missouri (MO), Arkansas (AR) and Louisiana (LA) are indicated. The right panel shows the mean vertical profiles observed by the CAMS and ISAF instruments, and simulated by GEOS-Chem, for the southeast US domain $\left(30.5-39^{\circ} \mathrm{N}, 95-81.5^{\circ} \mathrm{W}\right)$ defined by the black rectangle in the top left panel. Horizontal bars represent observed standard deviations. GEOS-Chem is sampled along the flight tracks at the time of the measurements. The dashed black line shows the mean vertical CAMS profile in marine air over the Gulf of Mexico $\left(22-28^{\circ} \mathrm{N}, 96.5-88.5^{\circ} \mathrm{W}\right)$, which is used in determining background HCHO column $\left(0.40 \times 10^{16}\right.$ molecules $\mathrm{cm}^{-2}$; see Sect. 3$)$. The bottom left panel shows the mean HCHO columns on a $0.5^{\circ} \times 0.5^{\circ}$ grid derived from the CAMS measurements after normalizing for temperature, for mixing depth and for the contribution from $\mathrm{HCHO}$ aloft (see text in Sect. 3).

the SAO retrievals and applied Eq. (1) to compute their values of $\Delta \Omega_{\mathrm{S}}$. For OMPS-PCA, we computed the AMF based on the reported $S(p), w(p)$ and $\mathrm{AMF}_{\mathrm{G}}$ using Eq. (3); computed $\Omega_{\mathrm{o}}$ based on the reported uncorrected and corrected VCDs; and then obtained $\Delta \Omega_{S}$ by Eq. (1).

\section{Aircraft observations and GEOS-Chem model simulation}

The SEAC ${ }^{4}$ RS DC-8 aircraft flew 21 flights over the southeast US between 5 August and 25 September 2013, providing extensive mapping of the mixed layer and vertical profiling from the mixed layer to the upper troposphere (Fig. 1). The mixed layer is defined here as the convectively unstable region of the atmosphere in contact with the ground, as measured from the aircraft by aerosol lidar (Browell et al., 1989; Hair et al., 2008; DIAL-HSRL Mixed Layer Heights README, 2014; Scarino et al., 2014). It typically extended to $1-3 \mathrm{~km}$ altitude $(\sim 700-900 \mathrm{hPa})$ during the afternoon. The mixed layer was often capped by a convective cloud layer of fair-weather cumuli extending to about $3 \mathrm{~km}$, with the free troposphere above (Kim et al., 2015). Ninety-five percent of flight hours were between 09:30 and 18:00 local time (LT) for the data in Fig. 1, and $78 \%$ in the afternoon. Diurnal variability of the $\mathrm{HCHO}$ columns is expected from models to be less than $10 \%$, assuming a correctly simulated diurnal photochemical cycle, since photochemistry is both a source and a sink (Millet et al., 2008; Valin et al., 2016).

Figure 2 (left panel) shows a point-to-point comparison of $1 \mathrm{~min}$ averaged ISAF and CAMS HCHO observations (R3 version) aboard the aircraft. There is excellent correlation in the mixed layer $(r=0.96)$ and above $(r=0.99)$. Reduced major axis (RMA) regression of the two data sets yields a slope of $1.10 \pm 0.00$, with ISAF being $10 \%$ higher than CAMS due to the fact that the two instruments are independently calibrated. This difference is generally within the 

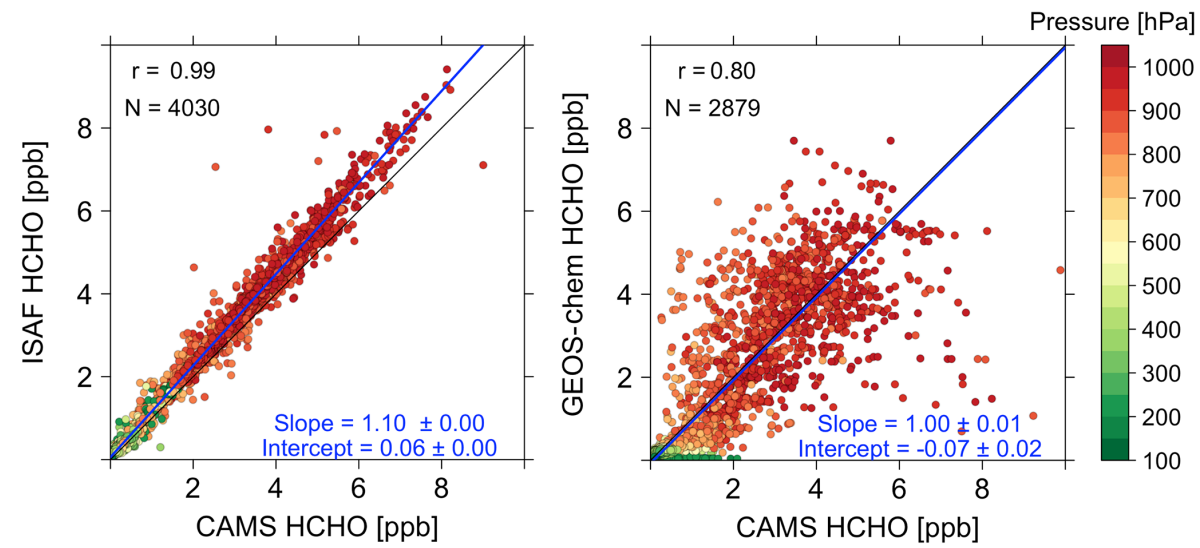

Figure 2. Comparisons between HCHO measurements from the CAMS and ISAF instruments aboard the SEAC ${ }^{4}$ RS aircraft, and simulated by GEOS-Chem, for the southeast US flight tracks (box in Fig. 1). The left panel compares 1 min measurements from CAMS and ISAF. The right panel compares GEOS-Chem and CAMS HCHO. Here and elsewhere for model-observation comparisons, HCHO observations along the flight tracks are averaged onto the GEOS-Chem grids $\left(0.25^{\circ} \times 0.3125^{\circ}, 47\right.$ vertical layers $)$ and time steps $(10 \mathrm{~min})$. HCHO data points are colored by atmospheric pressure. Slopes and intercepts of reduced major axis (RMA) regressions are shown along with the correlation coefficient $(r)$, sample size $(N)$, RMA regression line (in blue) and $1: 1$ line.

mutual stated accuracy for both instruments. The strong correlation between CAMS and ISAF provides confidence that they can be used for satellite validation purposes and suggests that they can be used as equivalent data sets after $10 \%$ bias correction. We use CAMS in what follows.

The aircraft data show high concentrations in the mixed layer due to biogenic isoprene emission and a sharp drop above the mixed layer because of the short lifetimes of isoprene $(\sim 1 \mathrm{~h})$ and of HCHO itself $(\sim 2 \mathrm{~h})$. Horizontal variability in the mixed layer reflects not only the density of isoprene-emitting vegetation but also surface air temperature (affecting isoprene emission) and mixing depth (affecting vertical mixing) at the time of the flights. We wish to convert the data to mean $\mathrm{HCHO}$ columns for the SEAC ${ }^{4} \mathrm{RS}$ period (5 August-25 September) in order to compare to the satellite data averaged over the same period. This requires time averaging of the local surface air temperature and mixing depth, and conversion of the mixed-layer concentration to a total column. We convert the aircraft $\mathrm{HCHO}$ mixing ratios in Fig. 1 to $\mathrm{HCHO}$ columns by assuming uniform $\mathrm{HCHO}$ mixing ratios from the surface up through the local mixing depth measured from the aircraft (DIALHSRL Mixed Layer Heights README, 2014), an exponential decay from the top of the mixed layer to $650 \mathrm{hPa}$ with a scale height of $1.9 \mathrm{~km}$ and a fixed background of $0.40 \times 10^{16}$ molecules $\mathrm{cm}^{-2}$ above, based on the mean vertical profiles information in Fig. 1. Day-to-day variability in $\mathrm{HCHO}$ columns in the southeast US is mainly driven by the temperature dependence of isoprene emission and can be fitted well by $\ln \Omega=0.11 T+2.62\left(r^{2}=0.64\right)$, where $\Omega$ is in units of $10^{15}$ molecules $\mathrm{cm}^{-2}$ and $T(\mathrm{~K})$ is the surface air temperature (Palmer et al., 2006; Zhu et al., 2014). We applied this temperature dependence to the local HCHO columns in- ferred from the aircraft mixed-layer data converted $\mathrm{HCHO}$ columns in order to correct for the difference between the local surface air temperature at the time of the flight and the local mean midday (12:00-13:00 LT) surface air temperature for the SEAC ${ }^{4} \mathrm{RS}$ period. Temperatures were taken from the Goddard Earth Observing System-Forward Processing (version 5.11.0, GEOS-FP hereafter) assimilated meteorological data product of the NASA Global Modeling and Assimilation Office (GMAO) (Molod et al., 2012).

The bottom left panel of Fig. 1 shows the resulting mean $\mathrm{HCHO}$ columns for the SEAC ${ }^{4} \mathrm{RS}$ period as inferred from the CAMS measurements. We estimate the error in this mean $\mathrm{HCHO}$ columns is $\sim 15 \%$, which is mainly from the mixing depths, assumed background, scale height and temperature dependence. The spatial distribution is markedly different and smoother than for the original mixed-layer data (top left panel), reflecting in large part the temperature normalization. Figure 3 shows the spatial distribution of midday temperatures for the SEAC ${ }^{4} \mathrm{RS}$ period, along with base isoprene emissions at $303 \mathrm{~K}$ from the MEGAN 2.1 model (Guenther et al., 2012). The base isoprene emissions feature a hot spot in the Ozarks region of southeast Missouri, where there is dense oak cover. This region was repeatedly sampled by the aircraft on hot days. The HCHO aircraft observations are particularly high there, but this feature is muted after correction for the mean August-September temperatures, which are much cooler in Missouri than further south. Inferred HCHO columns in Fig. 1 are instead highest over Arkansas and Louisiana, where August-September temperatures are high.

We simulated the $S E A C^{4} R S$ period using the GEOS-Chem v9-02 CTM (http://geos-chem.org) with $0.25^{\circ} \times 0.3125^{\circ}$ horizontal resolution over North America 

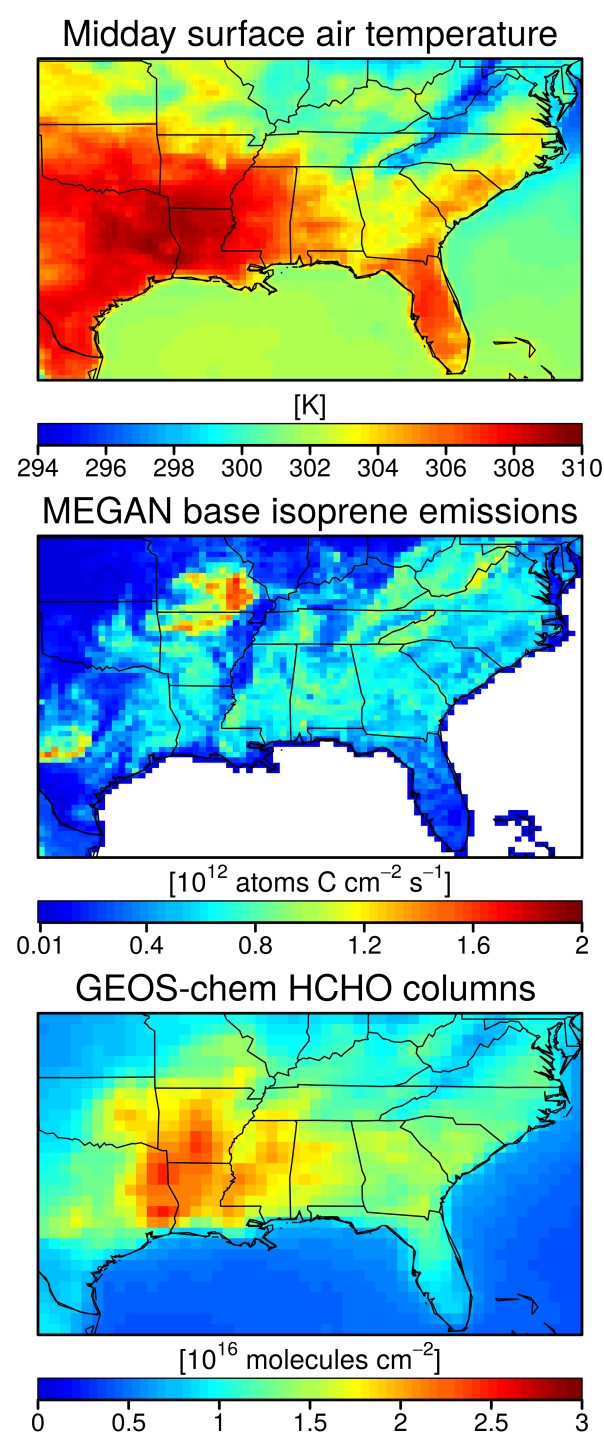

Figure 3. Mean temperature, base isoprene emissions and $\mathrm{HCHO}$ columns in the GEOS-Chem model for the SEAC ${ }^{4} \mathrm{RS}$ period (5 August-25 September 2013). The top panel shows the midday (12:00-13:00 LT) surface air temperature from the GEOSFP assimilated meteorological data. The middle panel shows the MEGAN 2.1 base isoprene emissions from Guenther et al. (2012) for standard conditions (air temperature $=303 \mathrm{~K}$; photosynthetic photon flux density $=200 \mu \mathrm{mol} \mathrm{m}^{-2} \mathrm{~s}^{-1}$ for sunlit leaves and $50 \mu \mathrm{mol} \mathrm{m} \mathrm{m}^{-2} \mathrm{~s}^{-1}$ for shaded leaves.) The bottom panel shows the GEOS-Chem HCHO columns computed with MEGAN 2.1 isoprene emissions and sampled at 13:30 LT, under OMI-SAO schedule, and filtered by OMI-SAO quality flags and cloud conditions.

driven by NASA GEOS-FP assimilated meteorological fields. The model has 47 vertical levels, including 18 below $3 \mathrm{~km}$. As can be seen in Fig. 4, initial simulations of the SEAC ${ }^{4} \mathrm{RS}$ data with GEOS-Chem pointed to a positive bias in the daytime GEOS-FP diagnostic for the height of the mixed layer (mixing depth), used in GEOS-Chem for

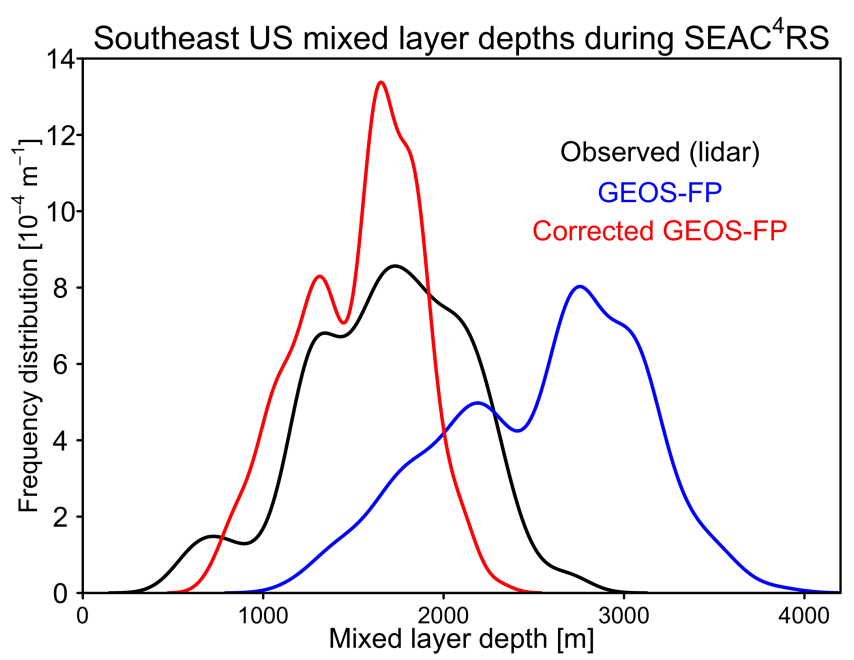

Figure 4. Frequency distribution of mixed layer depths over the southeast US during the SEAC ${ }^{4}$ RS period (5 August-25 September 2013). Observations by aerosol lidar aboard the aircraft (DIALHSRL Mixed Layer Heights README, 2014) are compared to the local GEOS-FP data used to drive GEOS-Chem, before and after the $40 \%$ downward correction. The frequency distributions are constructed from $1 \mathrm{~min}$ average data along the aircraft flight tracks over the southeast US (box in Fig. 1) for the 12:00-17:00 LT window.

surface-driven vertical mixing. Previous comparisons of GEOS-FP mixing depths to lidar and ceilometer data for other field studies in the southeast US found a 30-50\% high bias (Scarino et al., 2014; Millet et al., 2015). For the SEAC ${ }^{4} \mathrm{RS}$ simulation we decreased the GEOS-FP mixing depths by $40 \%$, and comparison to the aircraft lidar measurements along the DC-8 flight tracks shows that this corrects the bias (red line in Fig. 4). Corrected afternoon (12:00-17:00 LT) GEOS-FP mixing depths along the flight tracks in the southeast US average $1530 \pm 330 \mathrm{~m}$, compared to $1690 \pm 440 \mathrm{~m}$ in the lidar data.

Formaldehyde production in GEOS-Chem over the southeast US in summer is mainly from isoprene. Companion papers by Fisher et al. (2016), Marais et al. (2016) and Travis et al. (2016) describe the GEOS-Chem simulation of isoprene chemistry in SEAC ${ }^{4} \mathrm{RS}$ and comparisons to aircraft and surface observations. Biogenic VOC emissions are from the MEGAN 2.1 model as implemented in GEOS-Chem by Hu et al. (2015) and with a $15 \%$ decrease applied to isoprene (Wolfe et al., 2015). Surface-driven vertical mixing up to the mixing depth uses the non-local mixing scheme of Holtslag and Boville (1993), as implemented in GEOS-Chem by Lin and McElroy (2010).

Figure 2 (right panel) compares simulated and observed $\mathrm{HCHO}$ mixing ratios along the SEAC ${ }^{4} \mathrm{RS}$ flight tracks, averaged over the GEOS-Chem grid and time step. Comparison of the ensemble of data shows high correlation $(r=0.80)$ and no significant bias. Part of the correlation reflects the dependence on altitude, which is well captured by GEOS- 
Chem (Fig. 1, right panel). After removing this dependence on altitude (by only examining observations within the mixed layer), the correlation between model and observations remains high $(r=0.64)$, with only a small bias $(-3 \pm 2 \%)$ indicated by the RMA linear regression. GEOS-Chem is less successful in reproducing the $\mathrm{HCHO}$ concentrations in the free troposphere $(3-12 \mathrm{~km}, \sim 700-200 \mathrm{hPa}$ ), with a $-41 \%$ normalized mean bias. This may be due to insufficient deep convection in the model.

Integration of the mean vertical profiles in Fig. 1 indicates a mean GEOS-Chem HCHO column of $1.46 \times 10^{16}$ molecules $\mathrm{cm}^{-2}$ over the southeast US during the SEAC ${ }^{4} \mathrm{RS}$ period, which is $10 \%$ lower than observed by CAMS $\left(1.63 \times 10^{16}\right.$ molecules $\left.\mathrm{cm}^{-2}\right)$ and $23 \%$ lower than observed by ISAF $\left(1.90 \times 10^{16}\right.$ molecules $\left.\mathrm{cm}^{-2}\right)$. The spatial correlation between GEOS-Chem mean HCHO columns (Fig. 3, bottom panel) and the HCHO columns inferred from the CAMS data is 0.44 ( 0.47 for ISAF) on the $0.5^{\circ} \times 0.5^{\circ}$ grid, with GEOS-Chem capturing the region of maximum $\mathrm{HCHO}$ in Arkansas and Louisiana.

\section{Intercomparison and validation of satellite data sets over the southeast US}

Figure 5 shows the spatial distribution of mean $\mathrm{HCHO}$ columns over the SEAC ${ }^{4} \mathrm{RS}$ period taken from the six satellite retrievals of Table 1, along with values from GEOSChem and columns inferred from the CAMS aircraft observations. All retrievals feature high values over the southeast US due to isoprene emission and maximum values over and around Arkansas and Louisiana, consistent with GEOSChem and CAMS (Fig. 3).

Spatial correlation coefficients between $\mathrm{HCHO}$ columns for different pairs of satellite retrieval data in Fig. 5 are given in Table 2. The correlation coefficients are computed for the temporally averaged (5 August-25 September 2013) data on the $0.5^{\circ} \times 0.5^{\circ}$ grid of Fig. 5 for the southeast US domain (box in Figs. 1 and 5). Correlation coefficients for the different satellite retrievals are only 0.24-0.44 with CAMS but $0.38-0.85$ with GEOS-Chem and typically $0.4-0.8$ between pairs of retrievals. We conclude that there is consistency between retrievals in the spatial information even at the $0.5^{\circ}$ scale. The GOME2A-BIRA retrieval is noisier than the others, and we attribute this to degradation of the instrument after 7 years of operations rather than its reduced swath mode operated since July 2013 (De Smedt et al., 2015), because the noise of GOME2A columns is almost the same before and after the swath mode reduction.

We see from Fig. 5 that all retrievals are biased low relative to CAMS and GEOS-Chem. Table 3 gives statistics for these biases as spatial averages for the southeast US. GEOSChem columns are sampled on the same schedule and scenes as the individual retrievals, and are increased by $10 \%$ to correct for the bias with CAMS. Satellite retrieval biases rela-

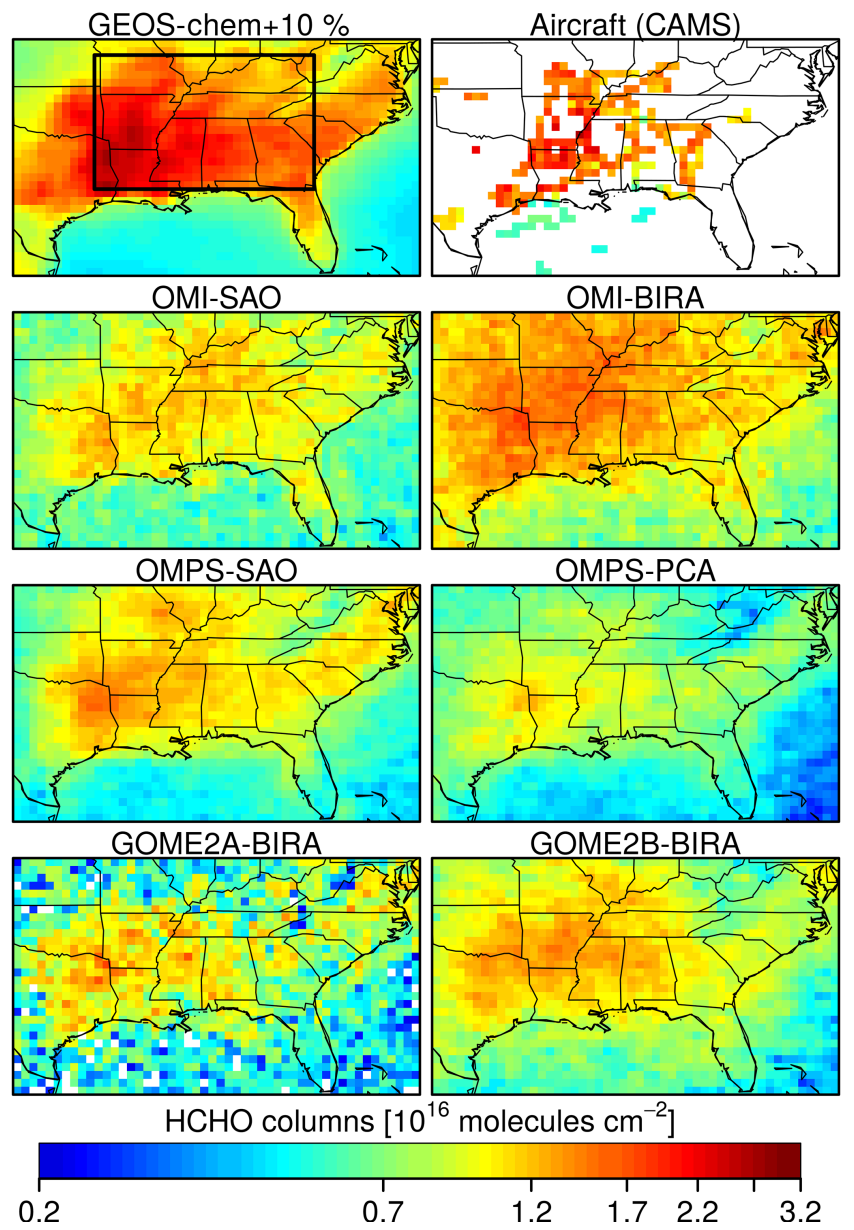

Figure 5. HCHO vertical column densities over the southeast US averaged over the SEAC ${ }^{4} \mathrm{RS}$ period (5 August-25 September 2013). The bottom panels show six retrievals from four satellites (OMI, GOME2A, GOME2B and OMPS) and three different groups (Table 1). The top panels show (1) GEOS-Chem model results sampled on the OMI schedule with filtering by OMI-SAO quality flags and cloud conditions, and increased by $10 \%$ to correct for the bias relative to CAMS aircraft measurements, and (2) columns derived from the CAMS aircraft measurements (same as bottom left panel of Fig. 1 but on a different color scale). The black rectangle represents the southeast US domain (same as in Fig. 1). Color bar is a logarithmic scale.

tive to the corrected GEOS-Chem values range from $-20 \%$ (OMI-BIRA) to $-51 \%$ (OMPS-PCA). The GOME2A and GOME2B observations are made at 09:30 LT, while the OMI and OMPS observations are made at 13:30 LT. GEOS-Chem columns increase by $6 \%$ from 09:30 to 13:30 LT, and this is accounted for in the GEOS-Chem comparisons of Table 3 .

Retrieval biases in the vertical column $\Omega$ could be contributed by the corrected slant column $\left(\Delta \Omega_{\mathrm{S}}\right)$, the AMF and the background correction $\Omega_{\mathrm{o}}$ (Eq. 1). Table 3 gives mean values for these different terms. We see that the OMI-BIRA column is the highest because it has the highest $\Delta \Omega_{\mathrm{S}}$ and 
Table 2. Spatial/temporal correlation coefficients $(r)$ between pairs of HCHO column products ${ }^{\mathrm{a}}$.

\begin{tabular}{|c|c|c|c|c|c|c|}
\hline $\mathrm{HCHO}$ product & $\begin{array}{r}\text { OMI-SAO } \\
(\mathrm{V} 003)\end{array}$ & OMI-BIRA & $\begin{array}{r}\text { GOME2A-BIRA } \\
(\mathrm{V} 14)\end{array}$ & $\begin{array}{r}\text { GOME2B-BIRA } \\
(\mathrm{V} 14)\end{array}$ & OMPS-SAO & OMPS-PCA \\
\hline OMI-SAO (V003) & $1 / 1$ & & & & & \\
\hline OMI-BIRA & $0.55 / 0.67$ & $1 / 1$ & & & & \\
\hline GOME2A-BIRA (V14) & $0.28 / 0.48$ & $0.38 / 0.50$ & $1 / 1$ & & & \\
\hline GOME2B-BIRA (V14) & $0.50 / 0.76$ & $0.65 / 0.60$ & $0.49 / 0.26$ & $1 / 1$ & & \\
\hline OMPS-SAO & $0.48 / 0.77$ & $0.70 / 0.50$ & $0.45 / 0.55$ & $0.72 / 0.76$ & $1 / 1$ & \\
\hline OMPS-PCA & $0.40 / 0.70$ & $0.60 / 0.51$ & $0.53 / 0.63$ & $0.71 / 0.68$ & $0.85 / 0.84$ & $1 / 1$ \\
\hline GEOS-Chem ${ }^{b}$ & $0.38 / 0.88$ & $0.50 / 0.65$ & $0.68 / 0.82$ & $0.85 / 0.88$ & $0.74 / 0.86$ & $0.82 / 0.75$ \\
\hline Aircraft $(\mathrm{CAMS})^{\mathrm{c}}$ & $0.24 /-$ & $0.44 /-$ & $0.26 /-$ & $0.35 /-$ & $0.43 /-$ & $0.37 /-$ \\
\hline
\end{tabular}

Table 3. Satellite retrievals of HCHO columns over the southeast US ${ }^{\mathrm{a}}$.

\begin{tabular}{l|rrrrrr|rrr|r}
\hline & \multicolumn{5}{|c|}{ Mean values $^{\mathrm{b}}$} & & \multicolumn{2}{|c|}{$\begin{array}{r}\text { With CAMS shape factors } \\
\text { GEOS-Chem } \\
+10 \%{ }^{\mathrm{c}}\end{array}$} \\
\hline Retrieval & $\Omega$ & $\Delta \Omega_{\mathrm{S}}$ & $\mathrm{AMF}_{\mathrm{G}}$ & $\mathrm{AMF}$ & $\Omega_{\mathrm{o}}$ & Bias $^{\mathrm{d}}$ & $\mathrm{AMF}^{\mathrm{e}}$ & $\Omega^{\mathrm{f}}$ & Bias $^{\mathrm{d}}$ & $\Omega^{2}$ \\
\hline OMI-SAO (V003) & 1.06 & 0.65 & 2.66 & 0.95 & 0.38 & $-37 \%$ & 1.01 & 0.96 & $-43 \%$ & 1.69 \\
OMI-BIRA & 1.33 & 0.87 & 2.62 & 0.88 & 0.31 & $-20 \%$ & 0.74 & 1.47 & $-12 \%$ & 1.67 \\
GOME2A-BIRA (V14) & 0.89 & 0.62 & 2.37 & 1.12 & 0.30 & $-44 \%$ & 1.14 & 0.84 & $-47 \%$ & 1.59 \\
GOME2B-BIRA (V14) & 1.09 & 0.86 & 2.56 & 1.22 & 0.30 & $-34 \%$ & 1.27 & 0.98 & $-41 \%$ & 1.65 \\
OMPS-SAO & 1.09 & 0.72 & 2.54 & 1.01 & 0.38 & $-34 \%$ & 1.02 & 1.01 & $-39 \%$ & 1.66 \\
OMPS-PCA & 0.80 & 0.49 & 2.53 & 1.11 & 0.35 & $-51 \%$ & 1.15 & 0.78 & $-52 \%$ & 1.63 \\
\hline
\end{tabular}

${ }^{a}$ Mean values over the southeast US domain (box in Figs. 1 and 5) for the data in Fig. 5 collected during the SEAC ${ }^{4}$ RS period (5 August-25 September 2013). ${ }^{b}$ Mean values provided as part of the retrieval product including vertical HCHO columns $(\Omega)$, corrected slant columns $\left(\Delta \Omega_{\mathrm{S}}\right)$, geometrical and scatter-corrected AMFs, and background correction $\left(\Omega_{\mathrm{o}}\right)$, following Eq. (1). Columns are in units of $10^{16}$ molecules $\mathrm{cm}^{-2}$, and AMFs are dimensionless. The corrected slant columns and background correction are not reported in the SAO and OMPS-PCA retrievals and are reconstructed here to enable comparison with the other retrievals (see Sect. 2). ${ }^{\mathrm{c}}$ GEOS-Chem columns sampled for the same scenes as the individual retrievals and increased by $10 \%$ to correct for the bias relative to the SEAC ${ }^{4}$ RS CAMS aircraft measurements (Fig. 1). Mean GEOS-Chem columns increase with time of day by 6.0\% from 09:30 LT (GOME2A and GOME2B) to 13:30 LT (OMI and OMPS). ${ }^{\mathrm{d}}$ Normalized mean bias relative to the corrected GEOS-Chem values (last column in the table). ${ }^{\mathrm{e}}$ AMFs recalculated using the mean HCHO vertical shape factor from the CAMS aircraft instrument (Figs. 1 and 6) and the scattering weights or averaging kernels provided as part of the satellite product (Fig. 6). ${ }^{\mathrm{f}}$ Columns recomputed using AMFs constrained by the CAMS aircraft measurements.

lowest AMF, while the OMPS-PCA column is the lowest because its $\Delta \Omega_{\mathrm{S}}$ is the lowest. OMPS-SAO and OMPS-PCA use the same OMPS spectra, but the OMPS-SAO $\Delta \Omega_{\mathrm{S}}$ are much higher and more consistent with the other retrievals. One caveat is that the derived $\Delta \Omega_{\mathrm{S}}$ of OMPS-PCA may not be the best measure for its algorithm sensitivity, since OMPS-PCA does not retrieve a slant column, nor does it subtract the Pacific SCD to remove offsets, as described in Sect. 2.

GOME2A-BIRA columns average $18 \%$ lower than GOME2B-BIRA despite sharing the same retrieval algorithm and overpass time. This reflects instrument degradation as pointed out above. GOME2A performed much better during its first 5 years of operation (2007-2011) (De Smedt et al., 2012, 2015).

The OMI-BIRA retrieval has the smallest bias relative to the GEOS-Chem and CAMS HCHO columns, and this is due in part to its low AMF (0.88). Figure 6 shows the mean reported scattering weights and shape factors for that retrieval (Eq. 3), in comparison to other retrievals and to the CAMS aircraft observations. OMI-BIRA has lower scattering weights than the other retrievals, contributing to the lower AMF, and we discuss that below. The shape factors in the SAO (from GEOS-Chem CTM with horizontal resolution of $2^{\circ} \times 2.5^{\circ}$ ) and BIRA retrievals (from the IMAGES CTM with horizontal resolution of $2^{\circ} \times 2.5^{\circ}$ ) underestimate $\mathrm{HCHO}$ in the boundary layer and overestimate it in the free troposphere. With the correct shape factor from CAMS the OMI-BIRA retrieval has an even lower AMF (0.74), as shown in Table 3, making it even better in comparison to GEOS-Chem and to the aircraft data. The shape factor from ISAF is consistent with that from CAMS (Fig. 1).

Table 3 also gives the AMFs for the other retrievals recomputed using CAMS shape factors. The differences with 

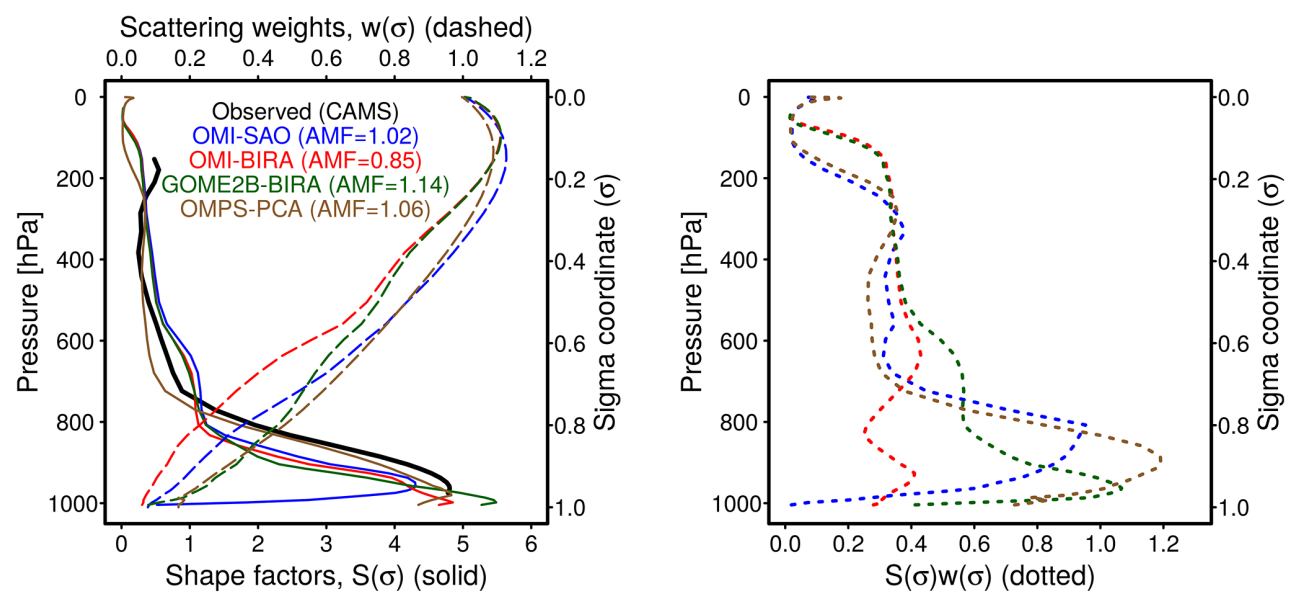

Figure 6. Air mass factor differences between retrievals. The left panel shows mean scattering weights $(w)$ and shape factors $(S)$ for HCHO retrievals over the southeast US during the SEAC ${ }^{4} \mathrm{RS}$ period, and the right panel shows the product of the two from which the AMF is derived by vertical integration using Eq. (3). Values are shown for the OMI-SAO, OMI-BIRA, GOME2B-BIRA and OMPS-PCA retrievals. Mean AMF values are given in the legend. Also shown is the observed HCHO shape factor (black) from the mean CAMS profile in Fig. 1.

the original AMFs are less than $6 \%$ except for OMI-BIRA $(14 \%)$. Although the results for OMI-BIRA illustrate how sensitive the AMF calculation is to the specification of shape factor, we find that this is not a significant source of bias in the other retrievals. This may reflect compensating errors in the vertical profile, as illustrated in Fig. 6 with the OMI-SAO shape factors in comparison with CAMS. We also compute AMFs using GEOS-Chem shape factors for each retrieval (Fig. S1 in the Supplement), but we find this makes no difference to the results.

When the AMFs for all retrievals are recomputed with common CAMS shape factors, as shown in Table 3, the remaining differences in AMFs are driven by viewing angles (as described by $\mathrm{AMF}_{\mathrm{G}}$ in Table 3), scattering weights and cloud parameters. Figure 6 shows that scattering weights are $10-30 \%$ higher in the OMI-SAO retrieval $(\mathrm{AMF}=1.02)$ than in the OMI-BIRA retrieval $(\mathrm{AMF}=0.85)$. The difference remains for cloud-free satellite pixels (cloud fraction $<0.01$ ) and so is not due to different treatments of cloud effects. Surface reflectivity averages 0.048 in OMI-SAO and 0.037 in OMI-BIRA. Although both use the OMI surface reflectance climatology of Kleipool et al. (2008), OMI-SAO applies monthly mean reflectivities while OMI-BIRA applies monthly minimum reflectivities. This can explain some though not all of the difference in scattering weights. De Smedt et al. (2008) found that the HCHO AMF increases from 0.4 to 4.0 when the surface albedo changes from 0 to 1 .

The background corrections $\left(\Omega_{0}=0.30\right.$ $0.38 \times 10^{16}$ molecules $\mathrm{cm}^{-2}$ ) in the different retrievals are all consistent and amount to about $30 \%$ of the mean $\Omega$ over the southeast US. They agree with background HCHO columns measured by aircraft over the remote North Pacific $\left(0.37 \pm 0.09 \times 10^{16}\right.$ molecules $\mathrm{cm}^{-2}$, Table 8 in Singh et al., 2009).
Previous studies have shown that variability in $\mathrm{HCHO}$ columns seen from space over the southeast US in summer is mainly driven by the temperature dependence of isoprene emission (Palmer et al., 2006; Millet et al., 2008; Duncan et al., 2009; Zhu et al., 2014). Figure 7 shows time series of daily HCHO columns averaged spatially over the southeast US for the OMI-SAO and OMI-BIRA retrievals. All retrievals have day-to-day temporal coherence consistent with the temperature dependence of isoprene emission. Temporal correlation between the daily HCHO column and midday temperature is 0.52 for GOME2A-BIRA, 0.59 for OMPSPCA, 0.59 for OMI-BIRA, 0.69 for GOME2A-BIRA, 0.71 for OMPS-SAO and 0.75 for OMI-SAO. GOME2A-BIRA shows the lowest correlation with temperature, again likely due to noise from instrument degradation.

$\mathrm{HCHO}$ over the southeast US in summer is mainly from oxidation of isoprene (Millet et al., 2006, 2008). Satellite retrievals validated in this study show consistency in capturing both spatial and daily variations in HCHO columns, as demonstrated by the indirect validation between SEAC ${ }^{4} \mathrm{RS}$ observations and satellite retrievals. This supports their use as a quantitative proxy for isoprene emissions. However, the systematic low bias (20-51\%) in the HCHO retrievals needs to be corrected. Our results show no indication of a pattern in the biases, suggesting that these could be removed as a uniform correction until better understanding is achieved.

\section{Conclusions}

We have used SEAC ${ }^{4} \mathrm{RS}$ aircraft observations of $\mathrm{HCHO}$ from two redundant in situ instruments over the southeast US for 5 August-25 September 2013, together with a GEOS-Chem chemical transport model simulation at 


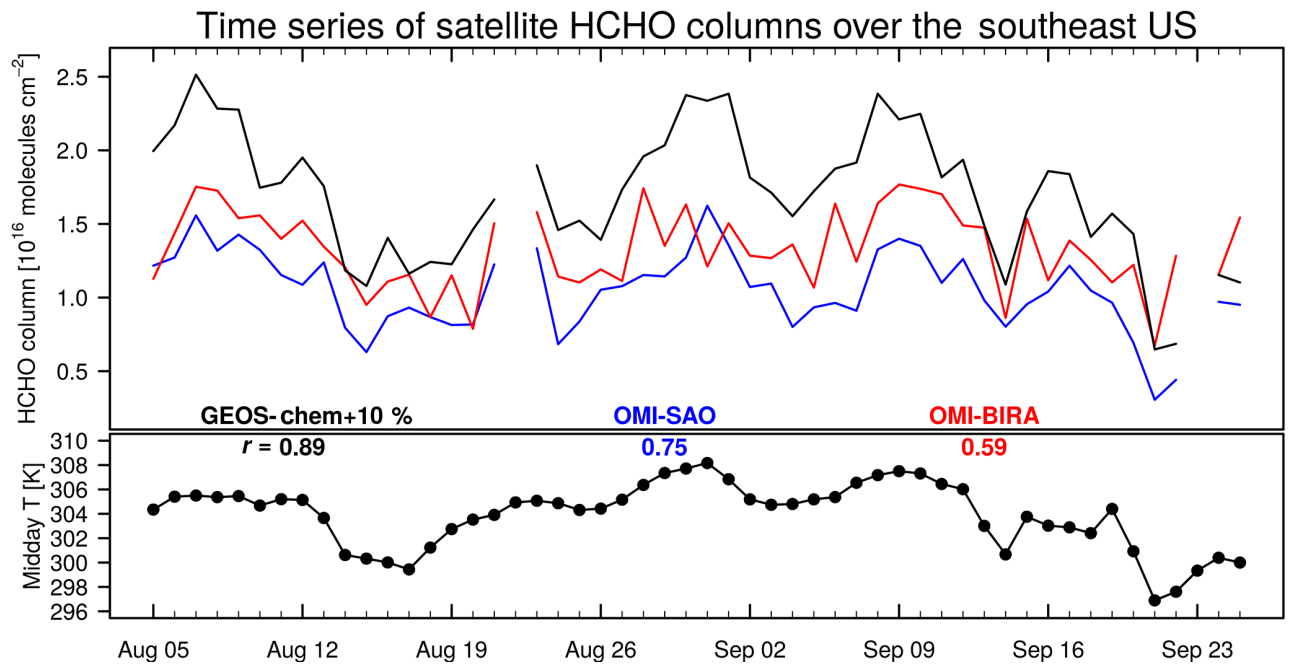

Figure 7. Daily variability of HCHO vertical column densities over the southeast US during SEAC ${ }^{4}$ RS. The top panel shows daily HCHO columns averaged over the southeast US (box in Fig. 5) for the OMI-SAO and OMI-BIRA retrievals. GEOS-Chem columns (black) are sampled following the OMI viewing geometry with filtering by OMI-SAO quality flags and cloud conditions, and scaled up by $10 \%$ on the basis of comparison with CAMS aircraft columns. The bottom panel shows the local midday (12:00-13:00 LT) surface air temperature over the southeast US domain from the GEOS-FP assimilated meteorological data. Also shown for each data set is the temporal correlation coefficient $(r)$ with temperature.

$0.25^{\circ} \times 0.3125^{\circ}$ horizontal resolution, to validate and intercompare six $\mathrm{HCHO}$ retrievals from four different satellite instruments operational during that period. The combination of aircraft data and GEOS-Chem model fields provides strong constraints on the mean $\mathrm{HCHO}$ columns and their variability over the southeast US, where high column amounts are driven by biogenic isoprene emission.

We find that the different retrievals show a large degree of consistency in their simulation of spatial and temporal variability. All retrievals capture the $\mathrm{HCHO}$ maximum over Arkansas and Louisiana seen in the aircraft data and in GEOS-Chem, and corresponding to the region of highest isoprene emission. Spatial correlation coefficients between retrievals are moderate to relatively high (0.4-0.8) even on a $0.5^{\circ} \times 0.5^{\circ}$ grid. All retrievals are also consistent in their simulation of day-to-day variability correlated with temperature. This supports the use of HCHO columns observed from space as a proxy for isoprene emission. GOME2A-BIRA (launched in 2006) is noisier than other retrievals. We attribute this to instrument degradation.

Despite this success and consistency in observing $\mathrm{HCHO}$ variability from space, we find that all satellite retrievals are biased low in the mean, by 20 to $51 \%$ depending on the retrieval. This would cause a corresponding bias in estimates of isoprene emission made from the satellite data. The bias is smallest for OMI-BIRA and could be further reduced by correcting the assumed HCHO vertical profiles (shape factors) assumed in the AMF calculation. Other retrievals have larger biases that appear to reflect a combination of (1) spectral fitting affecting the corrected slant columns and (2) scat- tering weights in the radiative transfer model affecting the AMF. Aside from OMI-BIRA, the shape factors used in the retrievals are not a significant source of error in determining the AMF

Our work points to the need for improvement in satellite $\mathrm{HCHO}$ retrievals to correct the mean low bias. We find no evident spatial or temporal pattern in the bias, at least for the southeast US in summer, that would compromise the interpretation of the satellite data to estimate patterns of isoprene emission. The biases may be removed by applying uniform correction factors until better understanding is achieved.

\section{Data availability}

SEAC ${ }^{4} \mathrm{RS}$ data are available at http://www-air.larc.nasa.gov/ missions/seac4rs/ (doi:10.5067/Aircraft/SEAC4RS/AerosolTraceGas-Cloud). OMI-SAO data were downloaded from http://disc.sci.gsfc.nasa.gov/Aura/data-holdings/OMI/ omhcho_v003.shtml. GOME2A-BIRA and GOME2BBIRA data were downloaded from http://h2co.aeronomie.be. Other satellite data were courtesy of the retrieval groups. 


\section{Appendix A}

Abbreviations and acronyms

\begin{tabular}{ll}
\hline AMF & Air mass factor \\
BIRA & Belgian Institute for Space Aeronomy \\
CAMS & Compact Atmospheric Multispecies Spectrometer \\
CTM & Chemical transport model \\
EUMETSAT & European Organisation for the Exploitation of Meteorological Satellites \\
GEOS-FP & Goddard Earth Observing System-Forward Processing \\
GMAO & Global Modeling and Assimilation Office \\
GMI & Global Modeling Initiative \\
GOME2 & Global Ozone Monitoring Experiment-2 \\
IMAGES & Intermediate Model of Global Evolution of Species \\
ISAF & In Situ Airborne Formaldehyde \\
MEGAN & Model of Emissions of Gases and Aerosols from Nature \\
OMI & Ozone Monitoring Instrument \\
OMPS & Ozone Mapping and Profiler Suite \\
PCA & Principal component analysis \\
RMA & Reduced major axis \\
SAO & (Harvard) Smithsonian Astrophysical Observatory \\
SCD & Slant column density \\
SCIAMACHY & Scanning Imaging Absorption spectroMeter for Atmospheric Chartography \\
SEAC ${ }^{4}$ RS & Studies of Emissions, Atmospheric Composition, Clouds and Climate Coupling by Regional Surveys \\
VCD & Vertical column density \\
VOCs & Volatile organic compounds
\end{tabular}




\section{The Supplement related to this article is available online at doi:10.5194/acp-16-13477-2016-supplement.}

Acknowledgements. We acknowledge contributions from the NASA SEAC ${ }^{4}$ RS science team. We would also like to thank the SEAC ${ }^{4} \mathrm{RS}$ flight crews and support staff for their outstanding efforts in the field. This work was funded by the US National Aeronautics and Space Administration. We thank Michel Van Roozendael for helpful discussions. Jenny A. Fisher acknowledges support from a University of Wollongong Vice Chancellor's Postdoctoral Fellowship. We thank three anonymous reviewers who provided thorough and thoughtful comments.

Edited by: R. Volkamer

Reviewed by: three anonymous referees

\section{References}

Barkley, M. P., De Smedt, I., Van Roozendael, M., Kurosu, T. P., Chance, K., Arneth, A., Hagberg, D., Guenther, A., Paulot, F., Marais, E., and Mao, J.: Top-down isoprene emissions over tropical South America inferred from SCIAMACHY and OMI formaldehyde columns, J. Geophys. Res. Atmos., 118, 68496868, 2013.

Bey, I., Jacob, D. J., Yantosca, R. M., Logan, J. A., Field, B., Fiore, A. M., Li, Q., Liu, H., Mickley, L. J., and Schultz, M.: Global modeling of tropospheric chemistry with assimilated meteorology: Model description and evaluation, J. Geophys. Res., 106, 23073-23096, 2001.

Browell, E. V.: Differential absorption lidar sensing of ozone, Proc. IEEE, 77, 419-432, 1989.

Callies, J., Corpaccioli, E., Eisinger, M., Hahne, A., and Lefebvre, A.: GOME-2- Metop's second-generation sensor for operational ozone monitoring, ESA Bull., 102, 28-36, 2000.

Cazorla, M., Wolfe, G. M., Bailey, S. A., Swanson, A. K., Arkinson, H. L., and Hanisco, T. F.: A new airborne laser-induced fluorescence instrument for in situ detection of formaldehyde throughout the troposphere and lower stratosphere, Atmos. Meas. Tech., 8, 541-552, doi:10.5194/amt-8-541-2015, 2015.

Chan Miller, C., Gonzalez Abad, G., Wang, H., Liu, X., Kurosu, T., Jacob, D. J., and Chance, K.: Glyoxal retrieval from the Ozone Monitoring Instrument, Atmos. Meas. Tech., 7, 38913907, doi:10.5194/amt-7-3891-2014, 2014.

Chance, K., Palmer, P. I., Spurr, R. J. D., Martin, R. V., Kurosu, T. P., and Jacob, D. J.: Satellite observations of formaldehyde over North America from GOME, Geophys. Res. Lett., 27, 34613464, 2000.

De Smedt, I., Müller, J.-F., Stavrakou, T., van der A, R., Eskes, H., and Van Roozendael, M.: Twelve years of global observations of formaldehyde in the troposphere using GOME and SCIAMACHY sensors, Atmos. Chem. Phys., 8, 4947-4963, doi:10.5194/acp-8-4947-2008, 2008.

De Smedt, I., Van Roozendael, M., Stavrakou, T., Müller, J.-F., Lerot, C., Theys, N., Valks, P., Hao, N., and van der A, R.: Improved retrieval of global tropospheric formaldehyde columns from GOME-2/MetOp-A addressing noise reduction and instrumental degradation issues, Atmos. Meas. Tech., 5, 2933-2949, doi:10.5194/amt-5-2933-2012, 2012.

De Smedt, I., Stavrakou, T., Hendrick, F., Danckaert, T., Vlemmix, T., Pinardi, G., Theys, N., Lerot, C., Gielen, C., Vigouroux, C., Hermans, C., Fayt, C., Veefkind, P., Müller, J.-F., and Van Roozendael, M.: Diurnal, seasonal and long-term variations of global formaldehyde columns inferred from combined OMI and GOME-2 observations, Atmos. Chem. Phys., 15, 12519-12545, doi:10.5194/acp-15-12519-2015, 2015.

DIAL-HSRL Mixed Layer Heights README File SEAC4RS 2013: http://www-air.larc.nasa.gov/cgi-bin/ArcView/seac4rs? MLH=1 (last access: 27 October 2016), 2014.

Dittman, M. G., Ramberg, E., Chrisp, M., Rodriguez, J. V., Sparks, A. L., Zaun, N. H., Hendershot, P., Dixon, T., Philbrick, R. H., and Wasinger, D.: Nadir ultraviolet imaging spectrometer for the NPOESS Ozone Mapping and Profiler Suite (OMPS), P. SPIE, 4814, 111-119, 2002.

Duncan B., Yoshida, Y., Damon, M., Douglass, A., and Witte, J.: Temperature dependence of factors controlling isoprene emissions, Geophys. Res. Lett., 36, L05813, doi:10.1029/2008GL037090, 2009.

Eskes, H. J. and Boersma, K. F.: Averaging kernels for DOAS totalcolumn satellite retrievals, Atmos. Chem. Phys., 3, 1285-1291, doi:10.5194/acp-3-1285-2003, 2003.

Fisher, J. A., Jacob, D. J., Travis, K. R., Kim, P. S., Marais, E. A., Chan Miller, C., Yu, K., Zhu, L., Yantosca, R. M., Sulprizio, M. P., Mao, J., Wennberg, P. O., Crounse, J. D., Teng, A. P., Nguyen, T. B., St. Clair, J. M., Cohen, R. C., Romer, P., Nault, B. A., Wooldridge, P. J., Jimenez, J. L., CampuzanoJost, P., Day, D. A., Hu, W., Shepson, P. B., Xiong, F., Blake, D. R., Goldstein, A. H., Misztal, P. K., Hanisco, T. F., Wolfe, G. M., Ryerson, T. B., Wisthaler, A., and Mikoviny, T.: Organic nitrate chemistry and its implications for nitrogen budgets in an isoprene- and monoterpene-rich atmosphere: constraints from aircraft (SEAC4RS) and ground-based (SOAS) observations in the Southeast US, Atmos. Chem. Phys., 16, 5969-5991, doi:10.5194/acp-16-5969-2016, 2016.

González Abad, G., Liu, X., Chance, K., Wang, H., Kurosu, T. P., and Suleiman, R.: Updated Smithsonian Astrophysical Observatory Ozone Monitoring Instrument (SAO OMI) formaldehyde retrieval, Atmos. Meas. Tech., 8, 19-32, doi:10.5194/amt-8-192015, 2015.

González Abad, G., Vasilkov, A., Seftor, C., Liu, X., and Chance, K.: Smithsonian Astrophysical Observatory Ozone Mapping and Profiler Suite (SAO OMPS) formaldehyde retrieval, Atmos. Meas. Tech., 9, 2797-2812, doi:10.5194/amt-9-2797-2016, 2016.

Guenther, A., Karl, T., Harley, P., Wiedinmyer, C., Palmer, P. I., and Geron, C.: Estimates of global terrestrial isoprene emissions using MEGAN (Model of Emissions of Gases and Aerosols from Nature), Atmos. Chem. Phys., 6, 3181-3210, doi:10.5194/acp-63181-2006, 2006.

Guenther, A. B., Jiang, X., Heald, C. L., Sakulyanontvittaya, T., Duhl, T., Emmons, L. K., and Wang, X.: The Model of Emissions of Gases and Aerosols from Nature version 2.1 (MEGAN2.1): an extended and updated framework for modeling biogenic emissions, Geosci. Model Dev., 5, 1471-1492, doi:10.5194/gmd-51471-2012, 2012. 
Hair, J. W., Hostetler, C. A., Cook, A. L., Harper, D. B., Ferrare, R. A., Mack, T. L., Welch, W., Izquierdo, L. R., and Hovis, F. E.: Airborne High Spectral Resolution Lidar for Profiling Aerosol Optical Properties, Appl. Optics, 47, 6734-6752, 2008.

Hewson, W., Barkley, M. P., Gonzalez Abad, G., Bösch, H., Kurosu, T., and Spurr, R.: Development and characterisation of a stateof-the-art GOME-2 formaldehyde air-mass factor algorithm, Atmos. Meas. Tech., 8, 4055-4074, doi:10.5194/amt-8-4055-2015, 2015.

Holtslag, A. and Boville, B.: Local versus nonlocal boundary-layer diffusion in a global climate model, J. Clim., 6, 1825-1842, 1993.

Hu, L., Millet, D. B., Baasandorj, M., Griffis, T. J., Turner, P., Helmig, D., Curtis, A. J., and Hueber, J.: Isoprene emissions and impacts over an ecological transition region in the US Upper Midwest inferred from tall tower measurements, J. Geophys. Res.-Atmos., 120, 3553-3571, 2015.

Khokhar, M., Frankenberg, C., Roozendael, M. V., Beirle, S., Kuhl, S., Richter, A., Platt, U., and Wagner, T.: Satellite observations of atmospheric $\mathrm{SO}_{2}$ from volcanic eruptions during the time-period of 1996-2002, Adv. Space Res., 36, 879-887, 2005.

Kim, P. S., Jacob, D. J., Fisher, J. A., Travis, K., Yu, K., Zhu, L., Yantosca, R. M., Sulprizio, M. P., Jimenez, J. L., CampuzanoJost, P., Froyd, K. D., Liao, J., Hair, J. W., Fenn, M. A., Butler, C. F., Wagner, N. L., Gordon, T. D., Welti, A., Wennberg, P. O., Crounse, J. D., St. Clair, J. M., Teng, A. P., Millet, D. B., Schwarz, J. P., Markovic, M. Z., and Perring, A. E.: Sources, seasonality, and trends of southeast US aerosol: an integrated analysis of surface, aircraft, and satellite observations with the GEOS-Chem chemical transport model, Atmos. Chem. Phys., 15, 10411-10433, doi:10.5194/acp-15-10411-2015, 2015.

Kleipool, Q. L., Dobber, M. R., de Haan, J. F., and Levelt, P. F.: Earth surface reflectance climatology from 3 years of OMI data, J. Geophys. Res., 113, D18308, doi:10.1029/2008JD010290, 2008.

Kurosu, T. P., Chance, K., and Sioris, C. E.: Preliminary results for $\mathrm{HCHO}$ and $\mathrm{BrO}$ from the EOS-Aura Ozone Monitoring Instrument, P. SPIE, 5652, 116-123, 2004.

Li, C., Joiner, J., Krotkov, N. A., and Dunlap, L.: A newmethod for global retrievals of HCHO total columns from the Suomi National Polar-orbiting Partnership Ozone Mapping and Profiler Suite, Geophys. Res. Lett., 42, 2515-2522, 2015.

Lin, J.-T. and McElroy, M.: Impacts of boundary layer mixing on pollutant vertical profiles in the lower troposphere: Implications to satellite remote sensing, Atmos. Environ., 44, 1726-1739, 2010.

Marais, E. A., Jacob, D. J., Kurosu, T. P., Chance, K., Murphy, J. G., Reeves, C., Mills, G., Casadio, S., Millet, D. B., Barkley, M. P., Paulot, F., and Mao, J.: Isoprene emissions in Africa inferred from OMI observations of formaldehyde columns, Atmos. Chem. Phys., 12, 6219-6235, doi:10.5194/acp-12-62192012, 2012.

Marais, E. A., Jacob, D. J., Jimenez, J. L., Campuzano-Jost, P., Day, D. A., Hu, W., Krechmer, J., Zhu, L., Kim, P. S., Miller, C. C., Fisher, J. A., Travis, K., Yu, K., Hanisco, T. F., Wolfe, G. M., Arkinson, H. L., Pye, H. O. T., Froyd, K. D., Liao, J., and McNeill, V. F.: Aqueous-phase mechanism for secondary organic aerosol formation from isoprene: application to the southeast United States and co-benefit of $\mathrm{SO}_{2}$ emission controls, At- mos. Chem. Phys., 16, 1603-1618, doi:10.5194/acp-16-16032016, 2016.

Martin, R. V., Parrish, D. D., Ryerson, T. B., Nicks Jr., D. K., Chance, K., Kurosu, T. P., Jacob, D. J., Sturges, E. D., Fried, A., and Wert, B. P.: Evaluation of GOME satellite measurements of tropospheric $\mathrm{NO}_{2}$ and $\mathrm{HCHO}$ using regional data from aircraft campaigns in the southeastern United States, J. Geophys. Res., 109, D24307, doi:10.1029/2004JD004869, 2004.

Millet, D. B., Jacob, D. J., Boersma, K. F., Fu, T. M., Kurosu, T. P., Chance, K., Heald, C. L., and Guenther, A.: Spatial distribution of isoprene emissions from North America derived from formaldehyde column measurements by the OMI satellite sensor, J. Geophys. Res., 113, D02307, doi:10.1029/2007JD008950, 2008.

Millet, D. B., Baasandorj, M., Farmer, D. K., Thornton, J. A., Baumann, K., Brophy, P., Chaliyakunnel, S., de Gouw, J. A., Graus, M., Hu, L., Koss, A., Lee, B. H., Lopez- Hilfiker, F. D., Neuman, J. A., Paulot, F., Peischl, J., Pollack, I. B., Ryerson, T. B., Warneke, C., Williams, B. J., and Xu, J.: A large and ubiquitous source of atmospheric formic acid, Atmos. Chem. Phys., 15, 6283-6304, doi:10.5194/acp-15-6283-2015, 2015.

Molod, A., Takacs, L., Suarez, M., Bacmeister, J., Song, I.-S., and Eichmann, A.: The GEOS-5 Atmospheric General Circulation Model: Mean Climate and Development from MERRA to Fortuna, NASA/TM-2012, 104606, 28, 1-124, 2012.

Palmer, P. I., Jacob, D. J., Chance, K., Martin, R. V., Spurr, R. J. D., Kurosu, T. P., Bey, I., Yantosca, R., Fiore, A., and Li, Q.: Air mass factor formulation for spectroscopic measurements from satellites: Application to formaldehyde retrievals from the Global Ozone Monitoring Experiment, J. Geophys. Res., 106, 1453914550, 2001.

Palmer, P. I., Jacob, D. J., Fiore, A. M., Martin, R. V., Chance, K., and Kurosu, T. P.: Mapping isoprene emissions over North America using formaldehyde column observations from space, J. Geophys. Res., 108, 4180, doi:10.1029/2002JD002153, 2003.

Palmer, P. I., Abbot, D. S., Fu, T.-M., Jacob, D. J., Chance, K., Kurosu, T. P., Guenther, A., Wiedinmyer, C., Stanton, J. C., Pilling, M. J., Pressley, S. N., Lamb, B., and Sumner, A. L.: Quantifying the seasonal and interannual variability of North American isoprene emissions using satellite observations of the formaldehyde column, J. Geophys. Res., 111, D12315, doi:10.1029/2005JD006689, 2006.

Richter, A., Weber, M., Burrows, J., Lambert, J.-C., and van Gijsel, A.: Validation strategy for satellite observations of tropospheric reactive gases, Ann. Geophys.-Italy, 56, doi:10.4401/ag6335, 2013.

Richter, D., Weibring, P., Walega, J. G., Fried, A., Spuler, S. M., and Taubman, M. S.: Compact highly sensitive multi-species airborne mid-IR spectrometer, Appl. Phys. B, 119, 119-131, 2015.

Rodriguez, J. M.: Chapter 6 in atmospheric effects of aviation: First report of the subsonic assessment project, in: Global Modeling Initiative, NASA Reference Publication, edited by: Thompson, A. M., Friedl, R. R., and Wesoky, H. L., National Aeronautics and Space Administration, Washington, DC, 123-145, 1996.

Scarino, A. J., Obland, M. D., Fast, J. D., Burton, S. P., Ferrare, R. A., Hostetler, C. A., Berg, L. K., Lefer, B., Haman, C., Hair, J. W., Rogers, R. R., Butler, C., Cook, A. L., and Harper, D. B.: Comparison of mixed layer heights from airborne high spectral resolution lidar, ground-based measurements, and the WR- 
FChem model during CalNex and CARES, Atmos. Chem. Phys., 14, 5547-5560, doi:10.5194/acp-14-5547-2014, 2014.

Shim, C., Wang, Y., Choi, Y., Palmer, P. I., Abbot, D. S., and Chance, K.: Constraining global isoprene emissions with Global Ozone Monitoring Experiment (GOME) formaldehyde column measurements, J. Geophys. Res., 110, D24301, doi:10.1029/2004JD005629, 2005.

Singh, H. B., Brune, W. H., Crawford, J. H., Flocke, F., and Jacob, D. J.: Chemistry and transport of pollution over the Gulf of Mexico and the Pacific: spring 2006 INTEX-B campaign overview and first results, Atmos. Chem. Phys., 9, 2301-2318, doi:10.5194/acp-9-2301-2009, 2009.

Stavrakou, T., Müller, J.-F., De Smedt, I., Van Roozendael, M., van der Werf, G. R., Giglio, L., and Guenther, A.: Global emissions of non-methane hydrocarbons deduced from SCIAMACHY formaldehyde columns through 2003-2006, Atmos. Chem. Phys., 9, 3663-3679, doi:10.5194/acp-9-3663-2009, 2009.

Toon, O. B., Maring, H., Dibb, J., Ferrare, R., Jacob, D. J., Jensen, E. J., Luo, Z. J., Mace, G. G., Pan, L. L., Pfister, L., Rosenlof, K. H., Redemann, J., Reid, J. S., Singh, H. B., Yokelson, R., Chen, G., Jucks, K. W., and Pszenny, A.: Planning, implementation and scientific goals of the Studies of Emissions and Atmospheric Composition, Clouds and Climate Coupling by Regional Surveys (SEAC4RS) field mission, J. Geophys. Res.-Atmos., 121, 4967009, doi:10.1002/2015JD024297, 2016.

Travis, K. R., Jacob, D. J., Fisher, J. A., Kim, P. S., Marais, E. A., Zhu, L., Yu, K., Miller, C. C., Yantosca, R. M., Sulprizio, M. P., Thompson, A. M., Wennberg, P. O., Crounse, J. D., St. Clair, J. M., Cohen, R. C., Laugher, J. L., Dibb, J. E., Hall, S. R., Ullmann, K., Wolfe, G. M., Pollack, I. B., Peischl, J., Neuman, J. A., and Zhou, $\mathrm{X} .: \mathrm{NO}_{x}$ emissions, isoprene oxidation pathways, vertical mixing, and implications for surface ozone in the Southeast United States, Atmos. Chem. Phys. Discuss., doi:10.5194/acp2016-110, in review, 2016.
Valin, L. C., Fiore, A. M., Chance, K., and González, Abad G.: The role of $\mathrm{OH}$ production in interpreting the variability of $\mathrm{CH}_{2} \mathrm{O}$ columns in the southeast US, J. Geophys. Res. Atmos., 121, 478493, 2016.

Vigouroux, C., Hendrick, F., Stavrakou, T., Dils, B., De Smedt, I., Hermans, C., Merlaud, A., Scolas, F., Senten, C., Vanhaelewyn, G., Fally, S., Carleer, M., Metzger, J.-M., Müller, J.-F., Van Roozendael, M., and De Mazière, M.: Ground-based FTIR and MAX-DOAS observations of formaldehyde at Réunion Island and comparisons with satellite and model data, Atmos. Chem. Phys., 9, 9523-9544, doi:10.5194/acp-9-9523-2009, 2009.

Wittrock, F., Richter, A., Oetjen, H., Burrows, J. P., Kanakidou, M., Myriokefalitakis, S., Volkamer, R., Beirle, S., Platt, U., and Wagner, T.: Simultaneous global observations of glyoxal and formaldehyde from space, Geophys. Res. Lett., 33, L16804, doi:10.1029/2006GL026310, 2006.

Wolfe, G. M., Hanisco, T. F., Arkinson, H. L., Bui, T. P., Crounse, J. D., Dean-Day, J., Goldstein, A., Guenther, A., Hall, S. R., Huey, G., Jacob, D. J., Karl, T., Kim, P. S., Liu, X., Marvin, M. R., Mikoviny, T., Misztal, P. K., Nguyen, T. B., Peischl, J., Pollack, I., Ryerson, T., St. Clair, J. M., Teng, A., Travis, K. R., Ullmann, K., Wennberg, P. O., and Wisthaler, A.: Quantifying sources and sinks of reactive gases in the lower atmosphere using airborne flux observations, Geophys. Res. Lett., 42, 8231-8240, 2015.

Zhu, L., Jacob, D. J., Mickley, L. J., Marais, E. A., Cohan, D. S., Yoshida, Y., Duncan, B. N., González Abad, G., and Chance, K. V.: Anthropogenic emissions of highly reactive volatile organic compounds in eastern Texas inferred from oversampling of satellite (OMI) measurements of HCHO columns, Environ. Res. Lett., 9, 114004, doi:10.1088/1748-9326/9/11/114004, 2014. 